\title{
Um olhar sobre o catolicismo brasileiro
}

\author{
Sandro Ramon Ferreira da Silva
}

SERBIN, Kenneth P. Padres, celibato e conflito social: uma história da Igreja católica no Brasil. Tradução Laura Teixeira Motta. São Paulo: Companhia das Letras, 2008.

Padres, celibato e conflito social: uma história da Igreja católica no Brasil é o título do último livro do historiador norte-americano, Kenneth Serbin, lançado no Brasil. Professor de História da Universidade de San Diego, Estados Unidos, Serbin é um brasilianista que tem se destacado nos estudos sobre a Igreja Católica brasileira. Anteriormente, um outro livro seu, Diálogos na sombra, lançado pela mesma editora em 2001, ganhou destaque ao examinar um grupo que contava com membros da alta hierarquia católica brasileira e homens da cúpula do regime civil-militar, que governou o país durante nossa última ditadura, analisando os esforços feitos por alguns de seus integrantes para manter um diálogo - durante os anos mais violentos do governo do general Médici - entre duas das mais antigas instituições do país: a Igreja e o Estado. A Comissão Especial Bipartite, como foi chamada, promoveu encontros sigilosos entre líderes católicos e generais, nos quais cada um dos lados apresentava suas críticas em relação ao outro. $\mathrm{Na}-$ quela que foi uma das maiores crises nas relações entre as duas instituiçôes, os membros mais progressistas da Igreja atacavam firmemente a política social do regime e defendiam, de forma cada vez mais contundente, a preservação dos direitos humanos. Os militares, por outro lado, exigiam um maior controle dos bispos sobre a parcela mais subversiva do clero, isto é, os progressistas, enquanto a Igreja exigia mais transparência do governo em assuntos como repressão e tortura.

Tanto aquele livro quanto o atual - Padres, celibato e conflito social - são fruto de anos de pesquisa. Segundo o autor, este último é o resultado de vinte anos de reflexão sobre a Igreja Católica no Brasil e de investigação na enorme documen- tação disponível nos vários institutos e congregaçôes que visitou aqui. Entrevistou dezenas de religiosos e pessoas ligadas à Igreja; examinou grande quantidade de periódicos; recorreu à iconografia enfim, teve acesso a uma enorme quantidade de fontes que serviram de lastro para as argumentações que levantou em seu texto. Além disso, estabeleceu um profícuo diálogo com a historiografia tradicional acerca da História da Igreja no Brasil. Entretanto, seu texto mantém os mesmos marcos cronológicos que a historiografia tradicional tem utilizado para balizar a história da Igreja no Brasil, ou seja, segue os mesmos limites temporais de nossas transformações políticas: períodos colonial, monárquico e republicano.

Já discorrendo sobre o primeiro período, Serbin propõe uma reflexão sobre o papel social do padre na colônia, a partir de uma perspectiva da Igreja como principal legitimadora da obra de colonização do território, importante articuladora das relações sociais e vigia da ordem moral. Ele apresenta a questão da formação do catolicismo popular no Brasil, mas não chega a trazer grandes novidades, pois remete, sobretudo, ao que já foi visitado e revisitado por outros historiadores. Como o próprio Serbin admite, ainda há muito que se pesquisar sobre a questão, pois pouco se sabe sobre as atividades dos padres seculares na história colonial. De fato, muito pouca atenção tem sido dada - até por falta de fontes primárias - por nossos historiadores, à ação do clero regular.

$\mathrm{Na}$ verdade, o autor apresenta uma visão panorâmica dos primeiros períodos da nossa história religiosa, o que permite ao leitor compreender melhor aquilo que me parece ser o cerne da sua pesquisa: a Igreja do tempo presente, configurada no pós-II Guerra Mundial. O autor tenta, desde o início, estabelecer um paralelo entre as ações do clero nacionalista e revolucionário do século XIX, como Diogo Feijó, os padres do patrocínio - grupo de religiosos da cidade paulista de Itu que preco- 
nizavam uma Igreja galicana e liberal - e os membros do seminário de Olinda e as atividades dos padres progressistas dos anos 1960 e 1970. Aliás, esta é uma questão central no seu texto: revelar as permanências, no século XX, de padrōes culturais e comportamentais já vivenciados nos tempos da colônia e do império.

Como o próprio título do livro sugere, a questão social e o celibato são os eixos do trabalho. Nessa perspectiva, Serbin reflete sobre o longo processo de romanização, iniciado pelo Vaticano ao final do século XIX, e o estabelecimento de um modelo de catolicismo tridentino na Igreja, especialmente nos seminários brasileiros, que teria forjado novos comportamentos de ordem moral entre os seminaristas e clérigos. Tal processo de romanização, que o autor conceitua como modernização conservadora, estabeleceu um novo paradigma para o sacerdócio, distinto daquele tão aceito no período colonial - como, por exemplo, quando a situação irregular do clero em relação ao celibato era acatada sem maiores resistências pela sociedade em geral. Ser "filho de padre", segundo o autor, era uma condição que poderia até propiciar distinção social para o indivíduo, uma vez que a prática do regime de concubinato por muitos clérigos não causava estranhamento nas populações.

Embora Serbin destaque a nova moral clerical, então estabelecida como um avanço da nova ordem tridentina pela mudança operada nas expectativas da sociedade em relação ao clero, chama a atenção para o isolamento social dos padres, resultado desse modelo de formação religiosa nos seminários, e para o rigor dessa formação, como fonte de distúrbios e dificuldades de ordem afetiva e sexual. Ainda sobre a romanização, ele vai pensá-la principalmente como um grande processo de europeização da Igreja no Brasil e um movimento de desnacionalização da instituição, destacando o papel central que muitas ordens religiosas voltaram a ocupar no cenário brasileiro, como os vicentinos, que vieram para o país com a finalidade de fazer com que o catolicismo nacional retornasse à grande disciplina da Igreja universal. Chama a atenção, ainda, para as missóes dos padres lazaristas que pregavam uma religião mais romanizada, embora não deixassem de dialogar com os valores do catolicismo po- pular. Traça uma breve trajetória da formação dos padres durante os primeiros decênios do período republicano, destacando avanços e retrocessos da Igreja nas dimensões pastoral, intelectual, disciplinar e social, compreendendo os problemas na vida religiosa como "os custos da disciplina".

Ao tratar da Igreja pós-1945 possivelmente o autor apresenta a sua maior contribuição ao debate historiográfico. Além de retomar a discussão sobre o despertar dos religiosos para as questôes sociais e a guinada de muitos seminaristas e clérigos para os movimentos de esquerda, ele esquadrinha com rigor o movimento dos seminaristas da década de 1960, quando exigiram o abandono do modelo tridentino para a formação dos sacerdotes no Brasil e criticaram o isolamento do clero, obstáculo a uma participação maior na vida do povo. Para Serbin, os seminaristas, em meio a uma grave crise de identidade, com a redefinição do novo papel social do clero, buscavam novos modelos de santidade que já não se encontravam no isolamento, mas, ao contrário, na vida com o povo e como povo. O novo paradigma para o sacerdócio já não seria o de um Alter Christus, mas "descer ao nível do povo". Serbin apresenta, então, um outro tema central no seu livro: "a inter-relação entre a oposição clerical ao regime militar, a busca por justiça social e a crise do sacerdócio".

É no contexto da crise do sacerdócio que expõe a experiência dos sacerdotes com a psicanálise e aquilo que chamou de "psicologia da libertação". Ao comparar os efeitos da já famosa teologia da libertação e da psicologia da libertação para a Igreja do Brasil, ele vai afirmar de forma bastante contundente que a segunda foi muito mais revolucionária do que a primeira. Para o autor, "a psicologia da libertação teve a dupla importância de livrar as pessoas tanto da pobreza de espírito e mente como das estruturas repressivas do catolicismo".

Em sua perspectiva, o contato com o mundo externo e as lutas sociais haviam ajudado a lançar o clero brasileiro em uma profunda crise de fé que poderia ser amenizada com o recurso à psicanálise. Seu argumento é que "o divã e a tribuna do orador definiram a Igreja brasileira em fins dos anos 1960". Talvez o autor tenha tomado a parte pelo todo, mas, de qualquer forma, o engajamento foi um dos aspectos da Igreja que ganhou mais visibilidade. 
Na discussão específica sobre a teologia da libertação ele também adota a mesma perspectiva $\mathrm{da}$ historiografia tradicional que indica a conferência dos bispos latino-americanos em Medellín, 1968, como momento inaugural do movimento. Este teria seu apogeu nos anos 1970 e a conferência de Santo Domingo, em 1992, como o momento de derrota da Igreja progressista. Serbin, portanto, mantém a lógica de que Medellín e Santo Domingo expressam respectivamente a ascensão e o declínio da teologia da libertação.

Apesar de ser um texto fundamental para qualquer um que queira refletir sobre a História da Igreja no Brasil, o trabalho de Serbin não foge de algumas limitações que têm persistido, ao que parece, na historiografia tradicional, tanto de ordem teórica quanto metodológica, principalmente no que concerne à história mais recente da instituição. Faz uma abordagem essencialmente política dos fatos, produzindo quadros explicativos que remetem ao entendimento de que toda ação da instituição visa, em última instância, apenas manter sua grande influência sobre o laicato e perpetuar o seu próprio poder; enfim, conservar o status quo. Este tipo de análise não lança mão de interpretações que levem em conta o ponto de vista dos muitos atores históricos envolvidos nos processos analisados. A Igreja e sua hierarquia não são quase nunca observadas segundo a sua própria visão de mundo, isto é, segundo os valores internos da instituição, mas quase sempre a partir de perspectivas externas e que lhes são de certa forma estranhas. De uma forma geral, as análises produzidas até aqui têm sido guiadas por concepções tributárias de certa filosofia marxista da história ou mesmo liberal, como parece ser o caso de Serbin. Seu lugar de fala revela sua visão bastante liberal do mundo, pois promove uma discussão que vai sempre pensar a democracia liberal como um valor universal, inquestionável e irresistível, destinada a todos os tempos e instituições. Como se toda a resistência da hierarquia à democratização da instituição fosse uma luta contra um destino certo e irrefutável. Essa percepção liberal parece provocar certa miopia em relação ao objeto da pesquisa. Por exemplo, ele compara a defesa que muitos bispos fizeram do ex-franciscano Leonardo Boff, quando este foi en- quadrado por Roma, e o quase total abandono da irmã Ivone Gebara, por parte dos bispos, quando ela esteve na mesma situação. Ora, o autor analisa a questão apenas do ângulo da discussão sobre gênero e sobre o machismo que vigora na instituição. Embora não seja meu objetivo simplesmente questionar esse último aspecto, penso que seria mais profícuo para a discussão historiográfica elaborar outros quadros explicativos e produzir novas conclusões. Entre outros propósitos, Leonardo Boff defendia o fim de uma Igreja hierárquica e a edificação de uma Igreja carismática e horizontal; já Ivone Gebara defendia abertamente a legalização do aborto. Suponho que poderia haver uma discussão sobre esses dois temas, segundo os próprios valores da Igreja, sua própria cultura política, sua própria moral, e não apenas discutir questões de gênero. Também isso, mas não apenas isso. Enfim, parece ser importante pensar a lógica interna da instituição, de acordo com a percepção que os muitos atores possuíam na conjuntura analisada, ou seja, captar as múltiplas interpretações que tais fatos ensejaram em todas as partes envolvidas. A proposta teórica do antropólogo Clifford Geertz - apenas a título de se pensar novas abordagens indica caminhos para isto, ao propor uma análise êmica dos fatos, isto é, tentar ver as coisas do ponto de vista de cada ator.

Como muitos autores, Serbin ratifica a lógica dos muitos embates entre o clero progressista no Brasil e na América Latina e a Santa Sé romana apenas como um confronto de interesses entre centro e periferia, ou, para alguns, entre superestrutura e estrutura.

$\mathrm{Na}$ excelente radiografia que faz da Igreja do Brasil, entretanto, o historiador lança luz sobre vários temas e questôes fundamentais da vida clerical nacional, mas poderia ter escapado do excessivamente politico e possibilitado novos ângulos e novos olhares sobre as relações sociais e culturais na Igreja do Brasil. Um tema que ainda me parece pertinente é a questão do celibato. Seu texto conduz a uma visão pouco matizada dessa instituição. Chama a atenção para os escândalos relativos a abusos sexuais praticados por religiosos, como assédio, homossexualismo, pedofilia - comparando sempre com a problemática da Igreja nos Estados Unidos -, interpretando o esforço de implantação 
da disciplina emanada de Roma e dos bispos, apenas como um aspecto da luta da instituição para garantir a manutenção do poder clerical. Não procura investigar a construção de sentido que muitos desses sujeitos davam à abstinência sexual, como um valor intrinsecamente espiritual, não abre espaço para a discussão do celibato como um valor transcendental arraigado na própria cultura cristã, desde os seus primeiros séculos.

Enfim, como já se afirmou aqui, o livro de Kenneth Serbin é fundamental para qualquer um que queira compreender melhor a história da Igreja Católica no Brasil, mas, ao mesmo tempo, sugere uma discussão ainda maior, isto é, a dos limites e permanências nas análises historiográficas produzidas sobre a Igreja contemporânea. Não seria o caso de iniciar um movimento revisionista dessa historiografia, extremamente centrada na discussão política? Não seria um bom momento para se lançar mão de novas teorias e novas metodologias advindas de outras áreas das ciências humanas e sociais, como a antropologia, a sociologia, a psicologia etc, para a construção de novos arcabouços e novos quadros explicativos? Em vez de explicaçóes exclusivamente centradas no plano político, por que não recorrer ao aparato conceitual da história cultural? Por que não pensar em construção de sentidos, representaçôes coletivas ou espaço simbólico? Talvez essas abordagens nos possibilitem vislumbrar um pouco melhor os fatos e os processos do ponto de vista de todos os seus atores envolvidos. 